\title{
Country-Specific Investment Motivations in Central Europe: Evidence from British Firms ${ }^{*}$
}

\author{
Shaukat Ali / Hafiz Mirza ${ }^{* *}$
}

The countries of Eastern and Central Europe have been progressing on the road to a market economy for a number of years now. UK companies, like other western firms, aware of the region's inhabitants pent-up desire for numerous consumer and industrial products and services have invested significantly. This paper presents empirical data of UK firms' country-specific motivations for investing in three Visegrád countries: Hungary Poland and the Czech Republic. Just over 40 per cent of the firms had investments in one country only. Various country-specific reasons were cited by the respondents, the significant of which were those relating to market-orientated factors and strategic factors. There was no statistical difference between the reasons chosen for each, except that of profit, where Hungary significantly differed from Poland and Czechia.

Die Länder Ost- und Mitteleuropas befinden sich nun schon einige Jahre auf dem Weg in die soziale Marktwirtschaft. Britische Unternehmen haben, wie andere westliche Firmen auch, hier erheblich investiert, da sie den unerschöpflichen Nachholbedarf der Einwohner dieser Länder bezüglich zahlreicher Konsum- und Investitionsgüter sowie Dienstleistungen erkannt haben. Der vorliegende Artikel basiert auf empirischen Daten zu länderspezifischer Investitionsgründen britischer Unternehmen in Polen, Tschechien und Ungarn. Die Befragten nannten vorwiegend marktorientierte und strategische Motive. Zwischen einzelnen Ländern konnten keine signifikanten Unterschiede festgestellt werden. Einzige Ausnahme hiervon bildet das Motiv 'Gewinnstreben' bei Investitionen in Ungarn.

Manuscript received: 17.6.96 revised: 20.1.97, accepted: 24.2.97

** Dr. Shaukat Ali, born 1960, Lecturer in International Business and Marketing, Assumption University, Bangkok, Thailand. His main research interests are the role of Foreign Direct Investment in Central \& Eastern Europe, The Internationalisation process of firms and International Strategy.

Professor Hafiz Mirza, born 1953, Head of the department of Business Economics and International Strategy, University of Bradford Management Centre, Emm Lane, Bradford, West Yorkshire, UK.

Mail address: Dr. Shaukat Ali, Graduate School of Business, Assumption University, Ramkhamhaeng Road, Soi 24, Huamark, 10240 Bangkok, Thailand

Tel.: +662 3004543

Email:shaukata@hotmail.com 


\section{Introduction}

Since the fall of the Iron-curtain, some six years, considerable change has occurred in Central and Eastern Europe, in all areas - political, economic and social - much of it difficult and painful (Buckley/ Ghauri 1994; Hooley et al. 1992; Marton 1993). It was envisaged that Western firms, aware of the region's inhabitants pent-up desire for numerous consumer and industrial products and services, would rush in with investment and transform the economies of these countries virtually overnight. Firms were further encouraged by the prospect of buying cheap assets via the various privatisation offerings.

However, the euphoria which gripped the West following this dramatic turn of events has given way to a more sombre assessment of business prospects in the region. Firms soon realised that along with opportunities come increased costs and complexities of doing business, and rather than instant profits success in the region comes from establishing a long-term presence in the market (Paliwoda 1995; Rojec/ Jamakowicz 1995).

Problems in the region were familiar: most sectors of the economy were characterised by heavy overmanning and starved of investment for over 40 years, a continous shortage economy resulted in growing, unsatisfied needs for a wide range of consumer and industrial goods (Kornai 1980, 1990). Having to deal with these problems was difficult enough, on top of this, the countries of the region were going through the political traumas associated with the jettisoning of the Communist system and the move to Western style democracies. Given such a background, it was not surprising that thoughts of instant profits soon evaporated.

The progress being made by many of the region's countries has been encouraging. Three countries in particular: the Czech Republic, Hungary and Poland are moving forward to become the 'motor economies' of the region. Poland and the Czech Republic were the first to climb out of the region's deep post-communist recession. Polish output began rising from mid-1992 with Czech recovery following a year later. In 1993 the Polish economy grew by some 3-4\%, with the Czechs achieving $0.5-1 \%$. The effects of a severe drought on farming in Hungary, coupled with export disappointments held the country back, but industrial output began to recover in the spring of 1993.

All three countries have now the basic framework of commercial law necessary to a market economy, including bankruptcy legislation to stiffen the financial discipline of both state and private sectors. High priority given to re-creating a market based banking system has had much success and all three of these countries have liberalised foreign trade and achieved current account convertibility of their national currencies. 
In achieving macro-economic stabilisation, micro-economic, technological and financial transformation of the countries, foreign direct investment, which brings with it much-needed management skills and technical know-how was expected to play a vital role (Vanous 1992; Inotai 1992; Bagó/ Kulcsár 1990). Furthermore, foreign direct investment was viewed as a linchpin in integrating these economies with the industrialised countries, particularly in Western Europe (Junz 1991), and in achieving major technological and managerial development (Simai 1989; Köves 1991; Marton 1993).

Despite the economic and political stakes involved, it is clear that FDI activity by UK firms is comparatively low and imbalanced across the region ( US $27 \%$, Germany $24.5 \%$, Austria $13.4 \%$, France $6.8 \%$, the UK just $4.8 \%)^{1}$. Furthermore the situation is complicated in that comparatively little Foreign Direct Investment has actually flowed into the region. By 1993, UNCTAD estimated that the cumulative FDI in the CEE and FSU (Former Soviet Union) was less than $\$ 17$ billion, or roughly three percent of the total FDI in developing countries, and more than half of that amount was concentrated in just two countries: Hungary, with $\$ 6.3$ billion, and the Czech Republic, with $\$ 2.8$ billion. In contrast, the one-year flow of FDI to China alone in 1993 was \$26 billion. The flow to the whole of Eastern Europe and the FSU was some $\$ 5$ billion, an amount less than that going to Thailand. India, another fast emerging destination for FDI, has in four years of economic reforms, approved (by August 1995) foreign direct investment worth $\$ 12$ billion. The US, which has already promised $\$ 1$ billion in the current financial year, has put in $\$ 3.33$ billion since the initiation of the reforms. In 1994, total inflows into CEE region, at $\$ 6$ billion, were lower than inflows to Singapore alone, and the regions cumulative stock was comparable to that of Argentina (UNCTAD 1994).

\section{Explaining investment in Central Europe}

A substantial body of literature exists to explain the motives for investing overseas (Beamish/ Banks 1987; Brewer 1993; Buckley 1989; Buckley/ Casson 1976; Casson 1987; Dunning/ Rugman 1985; Dunning 1988; Harrigan 1986; Hennart 1988, 1991a, 1991b; Lecraw 1992; Paliwoda 1993; Rugman/ Verbeke 1991; Terpstra/ Yu 1988), ranging from pre-empting competitors, following competitors, following clients, geographical diversity, achieving economies of scale, exploiting host government provisions, to utilising outdated technology etc.

Since the transition to a free market economy, various authors have attempted to explain the motives for investing in Central and Eastern Europe (Artisien et at 1993; Buckley/ Ghauri 1994; Engholm 1993; Howell 1994; Johnson/ Loveman 1995; Paliwoda 1995; Shama 1995; Williams 1993; Healey 1994). Governments

Accountancy, August 1995 
and local firms have been eager to benefit from transfers in capital, technology and managerial skills. Foreign firms, led by multinationals, have been eager to pursue new growth opportunities (Egan et al. 1995; Shama 1995).

Given the above, while knowledge of investment motives of firm into industrialised markets and many parts of the developing world is well established, this is not the case in Central and Eastern Europe. Indeed, because significant foreign investment into this region is occurring for the first time in the post war era, much can be learned about the "primary" mechanisms, motives, etc. of multinational firms. Hence whilst previous studies on the motives for investing were developed and tested on familiar markets, Central and Eastern Europe with its unique characteristics offers unique opportunities to test existing theories of investment.

This paper aims to highlight two main areas of research findings. First, it provides, for the first time, a broad overview of the characteristics of UK firms investing in the three Visegrád countries. Second, it attempts to ascertain whether previously identified investment motives in the literature still apply in a new context.

\section{Methodology}

The research instrument was a 7 part mail questionnaire, developed after an extensive literature review. It was piloted, resulting in a revised questionnaire, containing 54 open and closed ended questions which was mailed to named individuals in 732 firms (207 in Hungary, 250 in Poland and 275 in the Czech Republic). The companies involved were of different sizes, ranging from small to major multinationals, spread across many industry sectors. In total 145 questionnaires were returned, of which 134 were usable, representing a response rate of $24.2 \%$, which is acceptable given the length and complexity of the questionnaire (Hart 1987) in comparison with response rates obtained in the region by Hooley et al. $(1992,1995)$, using native researcher collaboration.

\section{Findings}

\section{Background to the findings}

In total 17 functions were represented, for Hungary and the Czech Republic the majority of the respondents were Chief Executive Officers (CEOs) and Managing Directors (43.18 per cent and 35.5 per cent respectively with only 14.3 per cent in the case of Poland). For Poland, the predominant category was marketing staff (45.3 per cent), with Hungary and the Czech Republic having similar proportions (34.1 per cent and 33.4 per cent respectively). Together these 
two categories accounted for 59.6 per cent, 77.2 per cent and 68.9 per cent of all respondents for Poland, Hungary and Czechia ${ }^{2}$.

Whilst marketing/sales/commercial managers/directors were targeted, it is an interesting fact that a relatively large number of CEOs in the UK (as opposed to those in the CEE countries, who due to the small size of the affiliates, in a sense had to answer the survey themselves) chose to answer the questionnaire personally, indicating that not only strategic investment decisions are being made at the highest levels as one would expect, but also, perhaps unexpectedly, that top management is personally monitoring the investment outcome and has direct knowledge of the business. The reverse position for the Polish case is not clear from the data, however possible reasons are that in Poland more subsidiaries are essentially sales and marketing operations, instead of production facilities, another is that Poland has more services firms. Another significant factor is the comparatively wide diversity of positions occupied by the respondents, adding richness and depth to the survey as well as providing a wide and disparate perspective to the investment climate in the three countries.

In an attempt to obtain a manifold perspective, the views of diverse companies were obtained. As a result, firms responding to the survey included banks, publishers, manufacturing and construction firms, business and management consultants, insurance and financial services, in total almost 90 separate business industries were represented. Grouping these categories into seven sectors gave manufacturing as the largest category (40 per cent), followed by services (26.8 per cent) and the financial sector (11.9 per cent).

Various industries such as transportation, communications and public utilities etc. as a group were the next largest category (10.4 per cent), followed by construction and wholesale/retail (both 3.7 per cent) and lastly natural resources (3 per cent). Within the three countries, Czechia has slightly more manufacturing firms (42 per cent) than both Hungary and Poland (38.8 and 38.1 per cent respectively). For services, Poland has a somewhat higher figure (31.2 per cent), while Hungary and Czechia are broadly similar (25.8 and 27.3 per cent respectively). Hungary and Poland are similarly represented in finance (15.8 and 14.3 per cent, respectively), though Czechia has far less (6.3 per cent). For the miscellaneous category, Hungary and Czechia are similar (13.6 and 12.6 per cent respectively), while there were only 4.8 per cent for Poland. For construction, Hungary and Poland are similar (4.6 and 4.8 per cent respectively) while only 2.1 per cent for Czechia. There is no firm involved in natural resources for the Hungarian sample, while there was some 6.3 and 2.4 per cent for Czechia and Poland respectively.

2 Often the term Czechia and the Czech Republic are used synomously. For ease of use, these terms may be used interchangeably, whenever it is appropriate. 
Table 1: Country-specific investment motives - Hungary

\begin{tabular}{|c|c|c|c|}
\hline MOTIVES & Mean & S.D. & $\mathbf{N}$ \\
\hline $\begin{array}{l}\text { UNIQUE FACTORS } \\
\text { Third party invitation }\end{array}$ & 1.87 & 1.26 & 16 \\
\hline MARKET-ORIENTATED & & & \\
\hline Additional profits or higher margins & 4.06 & 0.57 & 16 \\
\hline Market penetration & 3.27 & 1.22 & 16 \\
\hline Established local image & 2.44 & 1.46 & 16 \\
\hline Pre-empt competitors & 2.81 & 1.17 & 16 \\
\hline More developed market/business environment & 2.63 & 1.41 & 16 \\
\hline Overcome tariffs & 1.50 & 0.89 & 16 \\
\hline Follow competitors & 1.31 & 0.60 & 16 \\
\hline Utilise outdated technology & 1.44 & 1.09 & 16 \\
\hline Overcome import barriers & 1.44 & 0.89 & 16 \\
\hline Gain access to distribution network & 1.04 & 1.39 & 16 \\
\hline COST-ORIENTATED & & & \\
\hline Lower labour costs & 2.50 & 1.79 & 16 \\
\hline Availability of skilled labour & 2.44 & 1.55 & 16 \\
\hline To reduce transport costs & 1.13 & 0.50 & 16 \\
\hline SUPPLY FACTORS & & & \\
\hline Assure raw material supply & 1.60 & 1.06 & 15 \\
\hline Availability of better local support industries & 1.13 & 052 & 15 \\
\hline STRATEGIC FACTORS & & & \\
\hline Strategic location & 3.50 & 1.03 & 16 \\
\hline Geographical diversification & 2.69 & 1.14 & 16 \\
\hline Reduce financial risk & 1.94 & 1.39 & 16 \\
\hline Use/protect of patents/licenses & 1.31 & 1.01 & 16 \\
\hline INVESTMENT CLIMATE FACTORS & & & \\
\hline Better infrastructure & 2.75 & 1.13 & 16 \\
\hline Exploit host government investment provisions & 1.56 & 1.21 & 16 \\
\hline Psychic/cultural proximity & 1.19 & 0.40 & 16 \\
\hline
\end{tabular}

Importance of each factor: $1=$ not at all important, $2=$ not very important, $3=$ quite important, $4=$ very important, $5=$ extremely important

With regard to the size of firms in the survey the largest single category of firms (22) were those with employees greater than 30000 , the remaining employee sizes were widely dispersed with small and medium sized firms well represented. Grouping the firms into SMEs and large sizes gave the following picture $^{3 .}$ In total 72 firms in the sample were SMEs, whilst 59 were large. For individual countries the sample was similar with regard to the two categories. The Czech Republic had 27 (66.7 per cent) SMEs whilst Hungary and Poland 25

3 In this report small and medium sized firms are those with employees in the range 1-4 999, while those 5000 and over are classed as being large sized 
and 20 respectively (61.4 per cent and 57 per cent). For large firms the figures are 18,19 and 22 respectively (33.3 per cent, 38.6 per cent and 42.9 per cent).

\section{Country-specific motives}

The questionnaire asked firms "Why did you choose to expand into one country instead of another when investing in Central and Eastern Europe?". The firms were provided with a range of motives identified from the literature; they were also encouraged to add other motives if appropriate. Tables 1-3 show the responses. To aid comprehension, the motivation factors have been grouped.

There were 58 firms that had investments in only one country. From the total sample, 16 respondents had investment in Hungary only. Why did they choose Hungary and not other countries?. The answer is in the responses shown in Table 1.

The results show that main market-orientated reasons are profit and market penetration, established local image, pre-empt competitors and existence of a more developed market/business environment. The main cost-orientated reasons are lower labour costs and availability of skilled labour. For strategic factors, location and geographical diversification are both significant reasons. There was only one unique reason (third party invitation), but this was not judged to particularly important. For investment climate, better infrastructure was important but both government provisions and psychic/cultural consideration were not thought to be significant.

In the case of Poland the responses are shown in Table 2. There were 18 respondents who had investment in Poland only. Three of the significant unique reasons for choosing Poland were availability of complimentary skills, existing contacts and knowing well the country. For market-orientated reasons, higher profit was the only important reason, although market penetration, pre-empt competitors, established local image and existence of a more market/business environment all appeared to play some role in their choice to invest in Poland. Strategically, Poland was thought of as between quite and very important in terms of its location, with financial risk reduction and geographical diversification as important considerations. Investment climate factors do not appear to be attracted sufficient weight.

For the Czech Republic there were 24 respondents who had invested there only, a larger proportion than the other two countries. The responses are shown in Table 3. For unique factors, the important reasons are familiarity with the country, attitudes towards Europe (both thought to be extremely important), and well-equipped machinery. The last factor refers to the Czech Republic's reputation in the military hardware area. For many years it was the armament bread-basket of the Comecon countries. These skills, one suspects, are likely to 
assume increasing importance, both for outside investors and the Czechs themselves.

Table 2: Country-specific investment motives - Poland

\begin{tabular}{|l|c|c|c|}
\multicolumn{1}{|c|}{ MNOTIVES } & Mean & S.D. & N \\
Availability of complimentary skills & & & \\
Existing contacts & 5.00 & 0.00 & 1 \\
Knew country well & 3.00 & 0.00 & 1 \\
Third party invitation & 3.00 & 2.83 & 2 \\
\multicolumn{1}{|c|}{ MARKET-ORIENTATED } & 2.22 & 1.63 & 18 \\
Additional profits or higher margins & & & \\
Market penetration & 3.19 & 1.38 & 16 \\
Pre-empt competitors & 2.88 & 1.54 & 17 \\
Established local image & 2.76 & 1.56 & 17 \\
More developed market/business environment & 2.72 & 1.45 & 18 \\
Follow competitors & 2.00 & 1.12 & 18 \\
Gain access to distribution network & 1.39 & 0.61 & 18 \\
Overcome tariffs & 1.33 & 0.97 & 18 \\
Overcome import barriers & 1.22 & 0.43 & 18 \\
Utilise outdated technology $\quad 1.11$ & 0.32 & 18 \\
\multicolumn{1}{|c|}{ COST-ORIENTATED } & 1.06 & 0.24 & 18 \\
Lower labour costs & & & \\
Availability of skilled labour & 2.89 & 1.53 & 18 \\
To reduce transport costs & 2.72 & 1.49 & 18 \\
SUPPL FACTORS & 1.17 & 0.51 & 18 \\
Availability of better local support industries & 1.67 & 1.14 & 18 \\
Assure raw material supply & 1.61 & 1.04 & 18 \\
STRATEGIC FACTORS & & & \\
Strategic location & 3.50 & 1.25 & 18 \\
Reduce financial risk & 2.50 & 1.46 & 16 \\
Geographical diversification & 2.39 & 1.29 & 18 \\
Use/protect of patents/licenses $\quad 1.22$ & 0.94 & 18 \\
INVESTMENT CLIMATE FACTORS & & & \\
Better infrastructure & 2.00 & 1.08 & 18 \\
Psychic/cultural proximity & 2.00 & 1.37 & 18 \\
Exploit host government investment provisions & 1.67 & 0.91 & 18 \\
\hline
\end{tabular}

$1=$ not at all important, $2=$ not very important, $3=$ quite important, $4=$ =very important, $5=$ extremely important

Profits and market penetration are not surprisingly significant market-orientated reasons for choosing the Czech Republic, although pre-empt competitors and established local image also appear to be important. Lower labour cost and availability of skilled labour were the significant cost-orientated factors. An important supply factor was cited as work ethic (extremely important), although other factors do not appear to be important. Strategic factors thought to be significant are location and geographical diversification and to a lesser extent, financial risk reduction. For investment climate, political stability was cited as 
being extremely important. Given the fact that both Poland and Hungary have re-elected former communists in one form or another to power, this view is not surprising. A further consideration of importance was better infrastructure. A question arises from the above results: are any differences in the reasons chosen by firms to enter different countries instead of others statistically significant? Do some distinct country-specific factors emerge for any of the countries or are there no discernible reasons for choosing any country.

Table 3: Country-specific investment motives - Czech Republic

\begin{tabular}{|c|c|c|c|}
\hline MOTIVES & Mean & S.D. & $\mathbf{N}$ \\
\hline UNIQUE FACTORS & & & \\
\hline Familiar with country & 5.00 & 0.00 & 1 \\
\hline Attitude towards Europe & 5.00 & 0.00 & 1 \\
\hline Well-equipped machinery & 3.00 & 0.00 & 1 \\
\hline Third party invitation & 1.78 & 1.24 & 23 \\
\hline \multicolumn{4}{|l|}{ MARKET-ORIENTATED } \\
\hline Additional profits or higher margins & 3.13 & 1.23 & 24 \\
\hline Market penetration & 3.09 & 1.28 & 23 \\
\hline Pre-empt competitors & 2.74 & 1.45 & 23 \\
\hline Established local image & 2.61 & 1.20 & 23 \\
\hline More developed market/business environment & 2.44 & 1.39 & 24 \\
\hline Gain access to distribution network & 1.48 & 0.85 & 23 \\
\hline Follow competitors & 1.33 & 0.48 & 21 \\
\hline Overcome tariffs & 1.22 & 0.42 & 23 \\
\hline Utilise outdated technology & 1.09 & 0.29 & 23 \\
\hline Overcome import barriers & 1.04 & 0.21 & 23 \\
\hline \multicolumn{4}{|l|}{ COST-ORIENTATED } \\
\hline Lower labour costs & 3.04 & 1.20 & 24 \\
\hline Availability of skilled labour & 2.96 & 1.16 & 24 \\
\hline To reduce transport costs & 1.30 & 0.63 & 23 \\
\hline \multicolumn{4}{|l|}{ SUPPLY FACTORS } \\
\hline Work ethic & 5.00 & 0.00 & 1 \\
\hline Availability of better local support industries & 1.57 & 0.90 & 23 \\
\hline Assure raw material supply & 1.50 & 0.98 & 24 \\
\hline \multicolumn{4}{|l|}{ STRATEGIC FACTORS } \\
\hline Strategic location & 3.61 & 1.03 & 23 \\
\hline Geographical diversification & 3.13 & 1.10 & 23 \\
\hline Reduce financial risk & 2.04 & 1.26 & 23 \\
\hline Use/protect of patents/licenses & 1.3 & 0.88 & 23 \\
\hline INVESTMENT CLIMATE FACTORS & & & \\
\hline Political stability & 5.00 & 0.00 & 1 \\
\hline Better infrastructure & 2.43 & 1.31 & 23 \\
\hline Psychic/cultural proximity & 1.70 & 1.06 & 23 \\
\hline Exploit host government investment provisions & 1.35 & 0.71 & 23 \\
\hline
\end{tabular}


$1=$ not at all important, $2=$ not very important, $3=$ quite important, $4=$ very important, $5=$ extremely important

Using the five categories (market, cost, supply, strategic and investment climate factors), the Kruskal-Wallis Test is applied. Since unique factors are by definition particular to that country (other than third party invitation), they are not subject to the test but are included in the summary. As table 4 shows, apart from profitability where Hungary differed from the other two countries, there are no significant reasons for choosing one country over another. Particular firms, due to a range of unique factors such as previous contacts, decided to invest in that country. It is more than likely that, given limited resources, firms could only afford to invest in one country, and, given resources, would have chosen to invest in more than one country.

Table 4: Country-specific investment motives

\section{\begin{tabular}{c} 
Kruskal-Wallis H \\
\hline Investment motive \\
UNIQUE FACTORS \\
Third party invitation
\end{tabular}}

MARKET-ORIENTATED

Additional profits or higher margins

Market penetration

7.4698 Chi-square

Sig.

Pre-empt competitors

0.7874

0.6746

Establish local image

More developed market/business environment

0.6952

$0.0239 * *$

0.0251

0.7064

0.3430

0.9875

1.7499

0.8424

Gain access to distribution network

2.3413

0.4169

Follow competitors

0.2571

0.3102

Overcome tariffs

0.8775

0.8794

Utilise outdated technology

1.9215

0.6448

Overcome import barriers

4.0080

0.3826

0.1348

\section{COST-ORIENTATED}

Lower labour costs

0.9736

0.6146

Availability of skilled labour

0.9888

0.6099

To reduce transport costs

1.8432

0.3979

\section{SUPPLY FACTORS}

Availability of better local support industries

Assure raw material supply

$\begin{array}{ll}3.4871 & 0.1749 \\ 0.3380 & 0.8445\end{array}$

\section{STRATEGIC FACTORS}

Strategic location

0.4303

0.8064

Geographical diversification

3.8358

0.1469

Reduce financial risk

2.1119

0.3479

Use and protect patents/licenses

1.1249

0.5698

INVESTMENT CLIMATE FACTORS

Better infrastructure

Psychic/cultural proximity 
Exploit host government investment provisions

1.9060

0.3856

$* *=\mathrm{p}<0.05$

\section{Conclusions}

This paper had two aims: to profile UK firms' characteristics and to explore their investment motives. The first set of results showed that primary data supports secondary source information in that, UK investment is spread across all industries, both in manufacturing and services. Whilst large multinationals are the single largest category in the sample, there are many small and medium sized firms, confirming the wide dispersion of business activity. The Czech Republic had slightly more manufacturing firms, probably due to its advanced industrial base, largely in the armament area.

Just over 40 per cent of the firms had investments in one country only: 16 in Hungary, 18 in Poland and 24 in the Czech Republic. The investment motives, similar to previous literature, were grouped into five areas: market-orientated, cost-orientated, supply factors, strategic factors and the investment climate. A further category - unique factors - included those factors individual to some firms and necessary generally applicable.

Various country-specific reasons were cited by the respondents, none of which on its own, constituted the primary investment motive. There were a combination of reasons, the significant of which were those relating to marketorientated factors and strategic factors, which contributed to the choice of country. In the case of Poland one firm's choice to invest was determined by the availability of complementary skills, while in the Czech Republic familiarity with the country, attitude towards Europe, political stability and work ethic were deemed extremely important in the choice to invest there.

In comparing countries there was no statistical difference between the reasons chosen for each, except that of profit, where Hungary differed, which was significant at $p<0.05$. It appears that in Hungary firms were somewhat more influenced by profit than any other single factor.

In conclusion, the motives for investing in the countries of Central Europe appear to be broadly similar to those identified in previous studies, demonstrating that, in this context, the area is not viewed significantly different from other parts of the world. Different firms, using different sets of measures (often similar) have arrived at different conclusions as to where best prospects for their businesses lie.

\section{References}

Artisien, P./ Rojec, M./ Svetlicic, M. (1992) (eds.): Foreign Direct Investment in Central and Eastern Europe, London, Macmillan. 
Bagó, J./ Kulcsár, S. (1990): Experience with the establishment and operation of industrial joint ventures, in: Hungarian Scientific Council for World Economy (ed.): Foreign Direct Investment and Joint Ventures in Hungary: Experience and Prospects, Budapest.

Beamish, P.W./ Banks, J.C. (1987): Equity Joint Ventures and the Theory of the Multinational Enterprise, in: Journal of International Business Studies, summer.

Brewer, T. (1993): Government Policies, Market Imperfections and Foreign Direct Investment, in: Journal of International Business Studies, No. 24:1.

Buckley, P.J./ Casson, M. (1976): The Future of the Multinational Enterprise, London.

Buckley, P.J./ Casson, M. (1981): 'The optimal timing of a Foreign Direct Investment, in: The Economic Journal 92.

Buckley, P.J. (1989): Foreign Direct Investment by Small-and Medium-sized Enterprises, in: Small Business Economics, No. 1.

Buckley, P.J./ Ghauri, P.N. (1994) (eds.): The Economics of Change in Central and Eastern Europe, London.

Casson, M.C. (1987): The Firm and the Market, Oxford.

Dunning, J.D (1981): International Production and the Multinational Enterprise, London.

Dunning, J.H./ Rugman, A.M. (1985): The Influence of Hymer's Dissertation on the Theory of Foreign Direct Investment, in: American Economic Review, 75 May.

Dunning, J.H, (1988): Explaining International Production. Unwin Hyman.

Dyba, K./ Svejnar, J. (1991): Stabilization and Transition in Czechoslovakia, Paper prepared for NBER Conference on Eastern Europe, February 26-29.

Egan, C./ Shipley, D./ Neal, W./ Hooley, G./ Danko, J. (1995): Joint Ventures in Hungary: Expectations and Experience, Proceedings of the MEG Conference, University of Bradford.

Engholm, C. (1993): The Other Europe, McGraw Hill

Healey, N. (1994), The transition economies of Central and Eastern Europe: a political, economic, social and technological analysis, in: Columbia Journal of World Business, No. 29,1 .

Hare, P. (1993): Economic Prospects in Hungary: The rise of the Private Sector, in: Business Strategy Review, Vol. 4, No. 2.

Harrigan, K.R. (1986): Managing for Joint Venture Success, Lexington.

Hart, S. (1987): The use of the mail survey in industrial market research, in: Journal of Marketing Management, No. 3.

Hennart, J.F. (1988): A Transaction Cost Theory of Equity Joint Ventures, in: Strategic Management Journal, No. 9 (4).

Hennart, J.F. (1991a): The Transaction Cost Theory of Joint Ventures: An Empirical Study of Japanese Subsidiaries in the United States, in: Management Science, No. 37 (4).

Hennart, J.F. (1991b): Control in Multinational Firms: The Role of Price and hierarchy, in: Management International Review, Special Issue. 
Hooley, G.J./ Lynch, J.E./ Jobber, D. (1992): Generic Marketing Strategies, in: International Journal of Research in Marketing, No.1.

Hooley, G.J./ Shipley, D./ Beracs, J./ Kolos, K. (1995): Investing in Cherries and Resurrecting the dead: Foreign Direct Investment in Hungary, Proceeding of the MEG Conference.

Howell, J. (1994): Understanding Eastern Europe, London.

Inotai, A., (1992): Multinational Corporations in the East European Transformation, in: Klein, M.W./ Welfen P.J.J. (eds.): Multinationals in the new Europe and Global Trade, Berlin.

Johnson, S./ Loveman, G. (1995): Starting Over in Eastern Europe, Harvard Business School Press.

Junz, H.B. (1991): Integration of Eastern Europe into the world trading system, in: American Economic Review, No. 812 (May).

Kogut, B.(1983): Foreign direct investment as a sequential process, in: Kindleburger, C.P./ Audretsch, D. (eds): Multinational Corporations in the 1980s, Cambridge, Mass.

Kornai, J. (1980): The Economics of Shortage, Vol 1 and 2, Amsterdam.

Kornai, J. (1990): The Road to a Free Economy, New York.

Kot, J./ Dziura, M./ Piasecka, E./ Hardy, J./ Rainnie, A. (1995): The Flexible Firm goes East?, Proceedings of the 21 st EIBA conference, Italy.

Köves, A. (1991): A kifelé fordulás gyötrelmes útja, Közgazdasági Szemle, No. 38, March.

Lecraw, D.J. (1992): Mulitinational Enterprises in Developing Countries, in: Buckley, P.J. (ed): New Directions in International Business: Research Priorities for the 1990s, London.

Marton, K. (1993): Foreign Direct Investment in Hungary, Transnational Corporations, No.1.

Paliwoda, S. (1993): International Marketing, Oxford.

Paliwoda, S. (1995): Investing in Eastern Europe: Capitalizing on Emerging Markets, Addison Wesley.

Rojec, M./ Jermakowcz, W. (1995): Management Versus State in Foreign Privatizations in Central European Countries in Transition, Proceedings of the 21st EIBA conference, Urbino, Italy.

Rugman, A./ Verbeke, A. (1992): A Note on the Transnational Solution and the Tranaction Cost Theory of Multinational Strategic Management, in: Journal of International Business, No. 23 (4).

Rugman, A./ Lecraw, D./ Booth, L.D.(1985): International Business:Firm and Environment, McGraw-Hill.

Shama, A. (1995): Entry Strategies of US Firms to the Newly Independent States, Baltic States, and the Eastern European Countries, in: California Management Review, No.3, Spring.

Simai, M (1989): Külföldi müködótóke a szocialista országokban, Közgazdasági Szemle, 7-8.

Terpstra, V./ Yu, C.M. (1988): Determinants of Foreign Investment of CPS Advertising Agencies, in: Journal of International Business Studies, No. 19:1. 
UNCTAD (1994): Division on Transnational Corportions and Investment, World Investment Report, Geneva/ New York.

Vanous, J. (1992): Economic Recovery of Eastern Europe, PlanEcon Report, No.47.

Williams, K. (1993): Can Western Investments in Eastern Europe Succeed?, in: Management Accounting, No. 17. 